\title{
ANALISIS PEMERIKSAAN PAJAK TERHADAP SURAT PEMBERITAHUAN (SPT) TAHUNAN WAJIB PAJAK BADAN PADA KPP PRATAMA PALEMBANG SEBERANG ULU
}

\author{
Totok Sudiyanto *)
}

\begin{abstract}
ABSTRAK
Penelitian ini bertujuan untuk mengetahui bagaimana pemeriksaan pajak terhadap Surat Pemberitahuan (SPT) Tahunan Wajib Pajak Badan Pada KPP Pratama Palembang Seberang Ulu. Teknik analisis data yang digunakan adalah analisis data kualitatif, analisis data kualitatif untuk menganalisis pemeriksaan pajak terhadap Surat Pemberitahuan (SPT) tahunan yang dilakukan oleh KPP Pratama Palembang Seberang Ulu. Hasil dari penelitian ini menunjukkan bahwa ada beberapa pemeriksaan yang dilaksanakan oleh KPP Pratama Palembang Seberang Ulu dalam pemeriksaan pajaknya yaitu : pemeriksaan rutin ditujukan pada wajib pajak yang tidak melaksanakan kewajibannya yaitu menyampaikan Surat Pemberitahuan (SPT) dan wajib pajak yang melakukan pelanggaran. Pemeriksaan khusus ditujukan apabila wajib pajak yang diduga melakukan tindak pidana di bidang perpajakan, wajib pajak tertentu berdasarkan pengaduan masyarakat, serta wajib pajak tertentu berdasarkan pertimbangan Direktorat Jenderal Pajak. Pemeriksaan kriteria seleksi ditujukan untuk wajib pajak badan yang jumlah fiskalnya tinggi dan adanya indikasi yang kuat telah terjadi pelanggaran.
\end{abstract}

Kata Kunci : Pemeriksaan Pajak dan Surat Pemberitahuan (SPT) Tahunan.

\section{A. Latar Belakang}

Penerimaan negara sebagai sumber utama pembangunan nasional merupakan kegiatan yang bertujuan untuk mensejahterakan rakyat. Hal ini sejalan dengan tekad kemandirian bangsa dalam pembiayaan pembangunan negara guna mengurangi ketergantungan pada bantuan luar negeri. Untuk itu pula harus ditingkatkannya sumber dana yang ada di dalam negeri.

Pajak bagi negara adalah salah satu sumber penerimaan penting yang akan digunakan untuk membiayai pengeluaran negara, baik pengeluaran rutin maupun pengeluaran pembangunan. Proses pajak seharusnya bukan merupakan beban bagi wajib pajak melainkan harus disadari sebagai ungkapan rasa terima kasih kepada negara yang telah menghidupi dan menumbuhkembangkan berbagai keperluan masyarakat.

$$
\text { Fungsi Kantor Pelayanan Pajak }
$$
melakukan pemeriksaan pajak terhadap Wajib Pajak bukan untuk mencari kesalahan Wajib Pajak, tetapi untuk menguji kepatuhan pemenuhan kewajiban perpajakan dan/atau untuk tujuan lain dalam rangka melaksanakan ketentuan peraturan perundang-undangan perpajakan. Permasalahan yang dihadapi KPP Pratama Palembang Seberang Ulu adalah kurangnya pengetahuan wajib pajak tentang prosedur, pemotongan, pemungutan serta pelaporan Surat Pemberitahuan, kurangnya minat wajib pajak untuk mengetahui dan memahami peraturan perundangundangan perpajakan.

Alat yang sering digunakan untuk menilai kepatuhan wajib pajak adalah ketepatan waktu pelaporan SPT. Surat Pemberitahuan (SPT) merupakan dokumen yang menjadi alat kerjasama antara Wajib Pajak dan administrasi pajak, yang memuat datadata yang diperlukan untuk menetapkan secara tepat jumlah pajak yang terutang. Sesuai dengan prinsip self assesment system, Wajib Pajak harus melaporkan pajak bulanan dan pajak tahunannya. Dalam SPT 
tahunan, terdapat informasi mengenai jumlah PPh terutang yang dapat menjadi dasar untuk mengetahui besarnya peningkatan penerimaan pajak tiap tahunnya.
Dapat dilihat dari tabel data berikut jumlah wajib pajak yang efektif dan yang menyampaikan SPT Tahunan Wajib Pajak Badan :

\section{Tabel 1}

Jumlah Wajib Pajak Badan yang Efektif dan yang Menyampaikan SPT Tahunan Pada KPP Pratama Palembang Seberang Ulu 2014

\begin{tabular}{|c|c|c|c|c|}
\hline $\begin{array}{c}\text { Tahun } \\
\text { Pajak }\end{array}$ & $\begin{array}{c}\text { Jumlah } \\
\text { WP yang } \\
\text { Efektif }\end{array}$ & $\begin{array}{c}\text { Jumlah WP yang } \\
\text { menyampaikan } \\
\text { SPT Tahunan }\end{array}$ & $\begin{array}{c}\text { Jumlah SPT } \\
\text { yang diperiksa }\end{array}$ & $\begin{array}{c}\text { Jumlah SPT } \\
\text { yang tidak } \\
\text { diperiksa }\end{array}$ \\
\hline 2012 & 1.140 & 796 & 716 & 80 \\
\hline 2013 & 1.335 & 788 & 676 & 112 \\
\hline 2014 & 1.569 & 816 & 798 & 18 \\
\hline
\end{tabular}

Sumber: KPP Palembang Seberang Ulu 2014

Menurut Soemitro (2009:1) Pajak adalah iuran rakyat kepada Kas Negara berdasarkan Undang-Undang (yang dapat dipaksakan) dengan tiada mendapat jasa timbal balik (kontra prestasi) yang langsung dapat ditunjukkan dan yang digunakan untuk membayar.

Menurut Andriani (2011:2) Pajak adalah iuran kepada kas negara yang dapat dipaksakan yang terhutang oleh yang wajib membayarnya menurut peraturan perundang-undangan dengan tidak mendapat prestasi kembali, yang langsung dapat ditunjuk, dan yang digunakannya adalah untuk membiayai pengeluaran-pengeluaran umum berhubungan dengan tugas negara.

Menurut Pasal 1 UndangUndang No. 28 Tahun 2007, Wajib Pajak adalah orang pribadi atau badan yang menurut ketentuan peraturan perundang-undangan perpajakan ditentukan untuk melakukan kewajiban perpajakan termasuk pemungutan pajak atau pemotong pajak tertentu (Resmi, 2010:21). \begin{tabular}{llll}
\multicolumn{2}{r}{ Badan adalah sekumpulan } \\
orang dan atau modal yang \\
merupakan kesatuan baik yang
\end{tabular} melakukan usaha maupun yang tidak melakukan usaha yang meliputi perseroan terbatas, perseroan komanditer, perseroaan lainnya, badan usaha milik Negara atau Daerah dengan nama dan dalam bentuk apapun, firma, kongsi, koperasi, dana pensiun, persekutuan, perkumpulan, yayasan, organisasi sosial politik atau organisasi yang sejenis, lembaga bentuk usaha tetap dan bentuk usaha lainnya (Resmi, 2010:21).

Dalam Ketentuan dan Tata Cara Perpajakan, Undang-Undang Nomor 28 Tahun 2007 Pasal 1, Surat Pemberitahuan adalah surat yang oleh wajib pajak dipergunakan untuk melaporkan perhitungan dan atau pembayaran pajak, Objek Pajak dan atau bukan Objek Pajak dan atau harta dan kewajiban, menurut ketentuan peraturan perundang-undangan perpajakan (Resmi, 2010:21).

Pemeriksaan Pajak adalah serangkaian kegiatan untuk mencari, mengumpulkan, mengolah data dan 
atau keterangan lainnya untuk menguji kepatuhan pemenuhan kewajiban perpajakan dan untuk tujuan lain dalam rangka melaksanakan peraturan perundang undangan perpajakan (Rahman, 2010:249).

Tujuan pemeriksaan pajak juga disebutkan dalam ketentuan Pasal 29 UU KUP Keputusan Menteri Keuangan (llyas dan Burton, 2010:140) yaitu :

1. Untuk menguji kepatuhan pemenuhan kewajiban perpajakan dalam rangka memberikan kepastian hukum, keadilan dan pembinaan kepada wajib pajak.

2. Untuk tujuan lain dalam rangka melaksanakan ketentuan peraturan perundang-undangan.

\section{B. Rumusan Masalah}

Berdasarkan latar belakang dan identifikasi masalah serta batasan masalah diatas maka dapat dirumuskan bahwa bagaimana pemeriksaan pajak terhadap SPT Tahunan Wajib Pajak Badan pada Kantor Pelayanan Pajak (KPP) Pratama Palembang Seberang Ulu".

\section{Tujuan dan Manfaat Penelitian}

1. Tujuan Penelitian

Penelitian ini bertujuan untuk mengetahui pemeriksaan pajak terhadap SPT Tahunan wajib pajak badan pada Kantor Pelayanan Pajak (KPP) Pratama Palembang Seberang Ulu.

2. Manfaat Penelitian

a. Penelitian diharapkan dapat memperoleh pengetahuan dan lebih memahami tugas dan fungsi aparat pajak didalam mengamankan penerimaan negara, khususnya dari pelaksanaan pemeriksaan pajak.

b. Penelitian diharapkan dapat memberikan masukan bahwa pentingnya pemeriksaan pajak agar dapat lebih meningkatkan pengatahuan wajib pajak.

c. Penelitian diharapkan dapat dijadikan sebagai bahan pertimbangan penelitian lebih lanjut, dan dapat memberikan pengatahuan dalam bidang perpajakan.

\section{Metode Penelitian}

Analisis data yang digunakan dalam penelitian ini adalah data kualitatif, Data kualitatif adalah data yang berdasarkan teori yang relevan yang tidak bisa di ubah kembali. Data kualitatif yaitu Pemeriksaan Pajak terhadap SPT Tahunan Wajib Pajak Badan yang dilakukan oleh KPP Pratama Palembang Seberang Ulu.

\section{E. Variabel Operasional}

Agar penelitian ini mengarah dan tidak terlalu luas maka penulis membatasi variabel operasional sebagai berikut : Pemeriksaan Pajak Terhadap Surat Pemberitahuan Tahunan Wajib Pajak Badan.

Dari kedua Variabel diatas faktor-faktor yang digunakan sebagai indikator dalam penelitian ini adalah :

1. Pemeriksaan Rutin

Pemeriksaan yang bersifat rutin dilakukan terhadap wajib pajak sehubungan dengan pemenuhan hak dan kewajiban perpajakannya.

2. Pemeriksaan Khusus

Pemeriksaan ini dilaksanakan apabila SPT Tahunan wajib pajak orang pribadi atau badan terpilih untuk diperiksa berdasarkan sistem kriteria seleksi. Pemeriksaan kriteria seleksi difokuskan terhadap wajib pajak yang dikategorikan sebagai wajib pajak besar dan menengah, baik skala nasional, regional maupun lokal. Data yang dipergunakan sebagai dasar penetapan adalah data yang 
terdapat dalam Sistem Informasi Perpajakan.

3. Pemeriksaan Kriteria Seleksi

Pemeriksaan yang dilakukan terutama terhadap wajib pajak sehubungan dengan adanya keterangan atau masalah yang berkaitan dengannya.

\section{F. Teknik Pengumpulan data}

Dalam penelitian ini teknik pengumpulan data yang digunakan adalah :

1. Observasi

Yaitu suatu teknik mengumpulkan data secara langsung dengan cara mengamati langsung objek penelitian.

\section{Wawancara}

Yaitu dengan mengadakan tanya jawab secara langsung pada responden untuk menjawab permasalahan yang diteliti.

\section{G. Populasi dan Sampel}

Menurut Sugiyono (2009:115), populasi adalah wilayah generalisasi yang terdiri dari objek pajak yang mempunyai kualitas dan karakteristik tertentu yang diterapkan oleh penelitian untuk dipelajari dan kemudian ditarik kesimpulan. Menurut Sugiyono (2009:116), sampel adalah bagian dari jumlah dan karakteristik yang dimiliki oleh populasi tersebut. Populasi dan sampel dalam penelitian ini adalah seluruh pegawai KPP Pratama Palembang Seberang Ulu dan disajikan dalam bentuk tabel sebagai berikut:

\section{H. Pembahasan}

Pada Bab ini penulis akan membahas pemeriksaan pajak terhadap Surat Pemberitahuan Tahunan Wajib Pajak Badan pada KPP Pratama Palembang Seberang Ulu. Dasar atau sumber penelitian dalam penelitian ini adalah data-data yang berupa kondisi pemeriksaan pajak yang dilaksanakan terhadap para wajib pajak badan dalam wilayah kerja atau pengawasan Kantor Pelayanan Pajak Pratama Palembang Seberang Ulu selama kurun waktu 3 (tiga) tahun yaitu pemeriksaan pajak yang dilaksanakan mulai tahun 2012 sampai dengan pemeriksaan yang dilakukan tahun 2014.

Dalam penelitian ini penulis melakukan analisa atas data-data kegiatan sebelum pemeriksaan pajak sampai kepada pemeriksaan pajak yang dihasilkan untuk dapat diketahui apakah wajib pajak yang telah diperiksa dapat memenuhi kewajiban perpajakannya.

Berdasarkan data yang diperoleh dari Kantor Pelayanan Pajak (KPP) Pratama Palembang Seberang Ulu masih banyak wajib pajak yang tidak menyampaikan Surat Pemberitahuan (SPT) Tahunan secara benar, lengkap dan tepat waktu. Berikut data yang didapat dari Kantor Pelayanan Pajak (KPP) Pratama Palembang Seberang Ulu mengenai jumlah wajib pajak yang menyampaikan SPT dan setelah SPT disampaikan maka akan dilakukan pemeriksaan : 
Tabel. 2

\section{Jumlah Wajib Pajak Badan yang Efektif serta Menyampaikan SPT Tahunan Pada KPP Pratama Palembang Seberang Ulu}

\begin{tabular}{|c|c|c|c|c|}
\hline $\begin{array}{c}\text { Tahun } \\
\text { Pajak }\end{array}$ & $\begin{array}{c}\text { Jumlah } \\
\text { WP yang Efektif }\end{array}$ & $\begin{array}{c}\text { Jumlah WP } \\
\text { yang } \\
\text { menyampaikan } \\
\text { SPT Tahunan }\end{array}$ & $\begin{array}{c}\text { Jumlah } \\
\text { SPT yang } \\
\text { diperiksa }\end{array}$ & $\begin{array}{c}\text { Jumlah SPT } \\
\text { yang tidak } \\
\text { diperiksa }\end{array}$ \\
\hline 2012 & 1.140 & 796 & 716 & 80 \\
\hline 2013 & 1.335 & 788 & 676 & 112 \\
\hline 2014 & 1.569 & 816 & 798 & 18 \\
\hline
\end{tabular}

Sumber: KPP Palembang Seberang Ulu 2014

Berdasarkan data yang diperoleh dari KPP Pratama Palembang Seberang Ulu dapat dilihat bahwa jumlah wajib pajak yang efektif menyampaikan SPT setiap tahun tidak sama dengan jumlah wajib yang menyampaikan/mengembalikan SPT Tahunan, sebab setelah dilakukan pemeriksaan masih ada wajib pajak yang mengalami kesalahan dalam pengisian SPT Tahunan. Pada tahun 2012 hanya $69,8 \%$ wajib pajak yang menyampaikan SPT dan kemudian dilakukan pemeriksaan oleh pemeriksa pajak. Pada tahun 2013 mengalami penurunan sebesar $59,2 \%$, sedangkan pada tahun 2014 kembali mengalami penurunan sebesar 52\%. Adapun jumlah SPT yang tidak diperiksa pada tahun 2012 berjumlah 80 SPT, pada tahun 2013 berjumlah 112 SPT dan pada tahun 2014 berjumlah 18 SPT, SPT Tahunan yang tidak diperiksa akibat dari pengisian SPT yang tidak sesuai dengan prosedur/tata cara yang telah ditetapkan oleh Direktorat Jenderal Pajak.

Surat Pemberitahuan diperiksa agar tidak ada wajib pajak badan yang tidak menyampaikan Surat Pemberitahuan dan bisa melihat kepatuhan wajib pajak dalam menyampaikan Surat Pemberitahuan tepat pada waktunya. Untuk memastikan kebenaran data terhadap wajib pajak maka dapat dilakukan pemeriksaan, namun sebelum dilakukan pemeriksaan, terlebih dahulu pihak fiskus memberikan teguran terhadap wajib pajak yang tidak menyampaikan SPT tepat pada waktunya dan pengisian SPT yang tidak benar. Teguran itu antara lain dimaksudkan pula untuk memberi kesempatan kepada wajib pajak yang beritikad baik untuk menyampaikan alasan atau sebab tidak dapatnya SPT disampaikan apabila terjadi sesuatu diluar kemampuannya.

$$
\text { Kantor Pelayanan Pajak }
$$

Pratama Palembang seberang Ulu seharusnya dapat meningkatkan informasi perpajakan kepada masyarakat agar masyarakat mengetahui dan memahami tata cara pengisian SPT secara benar, dan lebih banyak mengadakan himbauan kepada wajib pajak sehingga dapat melaksanakan kewajibannya secara tepat waktu.

Adapun hambatan-hambatan yang sering ditemui oleh KPP Pratama Seberang Ulu dalam pemeriksaan Surat Pemberitahuan yaitu : wajib Pajak sulit ditemui, alamat wajib pajak fiktif dan atau wajib pajak sering berpindah-pindah, wajib pajak kurang kooperatif dalam membantu pemeriksaan pajak, wajib pajak tidak jujur dalam memberikan data-data yang berguna bagi pemeriksaan pajak 
Berdasarkan wawancara penulis dengan Kepala Seksi Pemeriksaan Pajak Penghasilan Badan KPP Pratama Palembang Seberang Ulu sebelum melakukan pemeriksaan pihak fiskus harus memenuhi prosedur pemeriksaan berikut ini :

1. Mengusulkan ke Kantor Wilayah (Kanwil) untuk meminta persetujuan atas usulan wajib pajak yang akan diperiksa.

2. Ada persetujuan dari Kantor Wilayah terhadap wajib pajak yang diusulkan untuk diperiksa.

3. Kantor Pelayanan Pajak (KPP) membuat Surat Tugas kepada Aparat dan sekaligus membuat Surat Pemberitahuan Pemeriksaan Pajak kepada wajib pajak tentang fungsi dan tujuan dilaksanakannya pemeriksaan pajak tersebut serta periode waktu pelaksana pemeriksaan pajak.

4. Memperkenalkan diri sebagai Aparat Pajak yang akan melaksanakan pemeriksaan serta menunjukkan Surat Tugas dan Kartu Tanda Pengenal kepada wajib pajak serta Surat peminjaman atas dokumen dan pembukuan yang berkaitan dengan usaha wajib pajak.

\section{a. Pemeriksaan Rutin}

Pemeriksaan pajak diharapkan dapat meningkatkan kepatuhan wajib pajak termasuk pemeriksaan dengan jenis pemeriksaan rutin. Hal ini juga disertai dengan adanya sanksi administrasi dan sanksi pidana yang diharapkan dapat menimbulkan efek jera terhadap wajib pajak yang tidak mengindahkan kewajibannya ataupun bagi wajib pajak yang menghindari pajak yang harus dibayar.
Tujuan dari pemeriksaan rutin adalah untuk memenuhi hak dan kewajiban wajib pajak. dalam artian wajib pajak membayar pajak sesuai dengan kondisi wajib pajak tersebut. Pemeriksaan rutin juga dilakukan diantaranya untuk memeriksa SPT lebih bayar. Pada dasarnya, pemeriksaan dilakukan adalah untuk menguji kepatuhan wajib pajak dalam memenuhi kewajiban perpajakannya dalam rangka pelaksanaan aturan perpajakan yang diatur di dalam Undangundang perpajakan. Dalam melakukan pemeriksaan rutin maka harus memenuhi kriteria pemeriksaan rutin, pelaksanaan pemeriksaan dan persiapan pemeriksaan.

Bagi wajib pajak yang melakukan kecurangan atau kesalahan dalam membayar pajak dan telat dalam menyampaikan SPT maka dapat dikenakan sanksi baik sanksi administrasi maupun sanksi pidana karena dengan sanksi tersebut pemerintah berharap wajib pajak akan patuh dalam memenuhi kewajibannya untuk membayar pajak sesuai dengan undangundang yang telah ditentukan.

Pemeriksaan Rutin dapat dilaksanakan dalam hal :

1. Wajib Pajak Orang Pribadi atau Badan Menyampaikan:
a. SPT Tahunan/SPT Masa yang menyatakan Lebih Bayar;

b. SPT Tahunan PPh untuk bagian tahun pajak sebagai akibat adanya perubahan tahun buku atau metode pembukuan atau penilaian kembali aktiva tetap yang telah disetujui oleh Direktur jenderal Pajak;

c. Wajib Pajak melakukan penggabungan, pemekaran, 


$\begin{array}{lr}\text { pengambilalihan } & \text { usaha, } \\ \text { atau likuidasi, } & \text { penutupan } \\ \text { usaha, atau } & \text { akan } \\ \text { meninggalkan } & \text { Indonesia } \\ \text { selama-lamanya; } & \end{array}$

2. Wajib Pajak Orang Pribadi atau Badan tidak menyampaikan SPT Tahunan/Masa dalam jangka waktu yang telah ditentukan dan setelah ditegur secara tertulis tidak menyampaikan SPT pada waktunya sebagaimana ditentukan dalam surat teguran;

3. Wajib Pajak Orang Pribadi atau Badan melakukan kegiatan membangun sendiri yang pemenuhan kewajiban PPN atas kegiatan tersebut patut diduga tidak dilaksanakan sebagaimana mestinya;

4. Wajib Pajak Orang Pribadi yang menjalankan usaha/pekerjaan bebas atau WP bdan yang mengajukan permohonan pencabutan NPWP atau perubahan tempat terdaftarnya WP dari suatu KPP ke KPP lain.

Pada Kantor Pelayanan Pajak Pratama Palembang Seberang Ulu dapat dilihat tabel dibawah ini, jumlah wajib pajak yang dilakukan pemeriksaan:

Tabel. 3

Data Pemeriksaan Rutin yang dilakukan oleh KPP Pratama Palembang Seberang Ulu

\begin{tabular}{|c|c|}
\hline Tahun Pajak & $\begin{array}{c}\text { Pemeriksaan } \\
\text { Rutin }\end{array}$ \\
\hline 2012 & 32 \\
2013 & 15 \\
2014 & 62 \\
\hline Jumlah & $\mathbf{1 0 9}$ \\
\hline
\end{tabular}

Sumber : KPP Palembang Seberang Ulu 2014

Berdasarkan data dari tabel sebanyak 109 wajib pajak yang dilakukan pemeriksaan rutin, pada tahun 2012 telah dilaksanakan pemeriksaan pajak sebanyak 32 wajib pajak, tahun 2013 sebanyak 15 wajib pajak, dan pada tahun 2014 sebanyak 62 wajib pajak yang dilakukan pemeriksaan. Pemeriksaan rutin diharapkan dapat meningkatkan kepatuhan wajib pajak, hal ini juga disertai dengan adanya sanksi administrasi dan sanksi pidana yang diharapkan dapat menimbulkan efek jera terhadap wajib pajak yang tidak mengindahkan kewajibannya ataupun bagi wajib pajak yang menghindari pajak yang harus dibayar.

Berdasarkan hasil penelitian kendala yang dihadapi dalam Pemeriksaan Rutin adalah apabila alamat wajib pajak tidak ditemukan dikarenakan wajib pajak telah pindah alamat. Dari hasil penelitian pemeriksaan rutin yang dilaksanakan oleh KPP Pratama Palembang Seberang Ulu terhadap semua SPT dapat diketahui jumlah wajib pajak yang tidak melaksanakan kewajibannya yaitu menyampaikan SPT dan wajib pajak yang melakukan pelanggaran dan akan berlanjut ke pemeriksaan khusus.

\section{b. Pemeriksaan Khusus}

Pemeriksaan

Khusus dilaksanakan apabila wajib pajak yang diduga melakukan tindak pidana di bidang perpajakan, wajib pajak tertentu berdasarkan pengaduan masyarakat, serta wajib pajak tertentu berdasarkan pertimbangan Direktorat Jenderal Pajak.

Pemeriksaan

Khusus berdasarkan instruksi dari Direktur Pemeriksaan dan Penagihan atau instruksi Kepala Kantor Wilayah DJP atau persetujuan Kepala Kantor Wilayah DJP dilakukan apabila terdapat hasil analisis dan pengembangan atau informasi, data, laporan, dan pengaduan. 
Analisis resiko adalah kegiatan yang dilakukan untuk menilai tingkat ketidakpatuhan Wajib Pajak yang berisiko menimbulkan kerugian penerimaan pajak terutama pada Wajib Pajak dengan risiko tinggi (high risk) yang dihitung dari potensi pajak yang masih dapat digali. Analisis resiko ini harus dibuat dengan mendasarkan pada profil Wajib Pajak termasuk aktivitas himbauan dan konseling yang telah dilakukan atas profil Wajib Pajak serta memanfaatkan data eksternal seperti informasi dari media massa atau lembaga/instansi terkait.
Alasan
dilakukannya

Pemeriksaan Khusus pada Kantor Pelayanan Pajak Pratama Palembang Seberang Ulu :

a. Terdapat hasil analisis dan pengembangan atas informasi, data, laporan, dan pengaduan yang dilakukan oleh Direktorat Intelijen dan Penyidikan yang perlu ditindaklanjuti.

b. Sebab lain berdasarkan pertimbangan Dirjen Pajak yang antara lain karena adanya permintaan dari Wajib Pajak tertentu, antara lain:

- WP BUMN

- WP yang kepemilikannya akan dialihkan; atau

- WP akan melakukan Emisi Saham/Obligasi.

c. Terdapat hasil analisis resiko secara komputerisasi (alias Kriteria Seleksi) yang berupa skor risiko ketidakpatuhan dengan memperhatikan variabel-variabel tertentu serta adanya data dan informasi.

Pada Kantor Pelayanan Pajak Pratama Palembang Seberang Ulu dapat dilihat tabel dibawah ini, jumlah wajib pajak yang dilakukan pemeriksaan:

Kemampuan karyawan dalam memberikan jasa pelayanan yang cepat dan baik dalam hal penjualan dengan jumlah responden yang memilih "Sangat Baik" sebanyak 11 responden dengan persentase sebesar 36,66 $\%$, dan pada atribut ini terdapat 6 responden yang memilih "Tidak Baik", hal ini juga menunjukkan bahwa kurang optimalnya kemampuan karyawan dalam memberikan jasa pelayanan yang cepat dan ramah dalam hal penjualan. Untuk itu bagi pihak perusahaan sebaiknya lebih meningkatkan lagi kinerja karyawan dalam hal pemberian jasa pelayanan yang cepat dan ramah dalam hal penjualan.

Tabel. 4

Data Pemeriksaan Khusus ang dilakukan oleh KPP Pratama Palembang Seberang Ulu

\begin{tabular}{|c|c|}
\hline Tahun Pajak & $\begin{array}{c}\text { Pemeriksaan } \\
\text { Khusus }\end{array}$ \\
\hline 2012 & - \\
2013 & 2 \\
2014 & 5 \\
\hline Jumlah & $\mathbf{7}$ \\
\hline
\end{tabular}

Sumber : KPP Palembang Seberang Ulu 2014

Berdasarkan data dari tabel diatas sebanyak 7 wajib pajak badan yang dilakukan pemeriksaan khusus, pada tahun 2013 telah dilaksanakan pemeriksaan pajak sebanyak 2 wajib pajak, dan tahun 2014 sebanyak 5 wajib pajak.

\section{c. Pemeriksaan Kriteria Seleksi}

Pemeriksaan

yang dilakukan terhadap wajib pajak badan atau wajib pajak orang pribadi yang terpilih berdasarkan 
skor rasio tinggkat kepatuhan secara komputerisasi.

Penggunaan sistem kriteria seleksi semacam ini dimaksudkan untuk mengurangi unsure subjektifitas dalam menentukan pilihan wajib pajak yang akan diperiksa, karena mekanisme pilihannya berdasarkan beberapa variabel yang sudah terukur dalam suatu program komputerisasi.

Berdasarkan sistem pemilihan seperti tersebut diatas, wajib pajak yang akan diperiksa adalah wajib pajak yang mempunyai potensi fiscal tinggi, tetapi menunjukkan adanya indikasi telah melakukan pelanggaran terhadap kewajiban perpajakannya. Pemeriksaan kriteria seleksi bertujuan untuk mengurangi unsur subjektif didalam pemilihan wajib pajak yang akan dilakukan pemeriksaan. Hal ini dilakukan apabila diketahui bahwa wajib pajak tersebut mempunyai potensi perpajakan yang tinggi atau menunjukkan indikasi yang kuat telah terjadi pelanggaran terhadap kewajiban perpajakan yang dilakukan oleh wajib pajak tersebut.

Kantor Pelayanan Pajak Pratama Palembang Seberang Ulu yang peneliti ketahui selama periode 3 (tiga) tahun berdasarkan data belum melakukan pemeriksaan kriteria seleksi, sebab pemeriksaan kriteria seleksi memang ditujukan untuk wajib pajak badan yang jumlah fiskalnya tinggi dan adanya indikasi yang kuat telah terjadi pelanggaran.

\section{KESIMPULAN DAN SARAN \\ 1. Kesimpulan}

Berdasarkan hasil penelitian yang dilakukan penulis maka dapat ditarik kesimpulan sebagai berikut:
Pemeriksaan pajak yang dilaksanakan oleh KPP Pratama Palembang Seberang Ulu dalam penelitian yaitu pemeriksaan rutin, pemeriksaan khusus dan pemeriksaan kriteria seleksi pada KPP Pratama Palembang Seberang Ulu.

Pemeriksaan Rutin yang dilaksanakan oleh KPP Pratama Palembang Seberang Ulu terhadap semua SPT dapat diketahui jumlah wajib pajak yang tidak melaksanakan kewajibannya yaitu menyampaikan SPT dan wajib pajak yang melakukan pelanggaran dan akan berlanjut ke pemeriksaan khusus.

Pemeriksaan khusus ditujukan apabila wajib pajak yang diduga melakukan tindak pidana di bidang perpajakan, wajib pajak tertentu berdasarkan pengaduan masyarakat, serta wajib pajak tertentu berdasarkan pertimbangan Direktorat Jenderal Pajak.

Pemeriksaan kriteria seleksi ditujukan untuk wajib pajak badan yang jumlah fiskalnya tinggi dan adanya indikasi yang kuat telah terjadi pelanggaran.

\section{Saran}

Adapun saran yang dapat penulis sampaikan dari penelitian ini adalah bagi Kantor Pelayanan Pajak (KPP) Pratama Palembang Seberang Ulu diharapkan aparat pajak dapat meningkatkan informasi perpajakan kepada masyarakat agar masyarakat mengetahui dan memahami tata cara pengisian SPT secara benar, dan lebih banyak mengadakan himbauan kepada wajib pajak sehingga dapat melaksanakan kewajibannya secara tepat waktu. 


\section{DAFTAR PUSTAKA}

Abdul Rahman, 2010. Administrasi Pajak, Bandung : Nuansa

Mardiasmo, 2011. Perpajakan (Edisi Revisi 2011), Yogyakarta : Andi Yogyakarta

Miranty, 2008. Analisis Tata Cara Pemeriksaan Pajak Terhadap Surat Pemberitahuan Tahunan Wajib Pajak Badan Pada KPP Pratama Palembang Seberang Ulu (Dipublikasikan).

Peraturan Menteri Keuangan, Nomor 181/PMK.03/2007 tentang Bentuk dan Isi Surat Pemberitahuan, serta Tata Cara Pengambilan, Pengisian dan Penandatanganan dan Penyampaian Surat Pemberitahuan sebagaimana telah diubah dengan Peraturan Menteri Keuangan Nomor 152/PMK.03/2009.

Republik Indonesia, 2000. UndangUndang Nomor 28 Tahun 2007 Tentang Perubahan Ketiga Atas Undang-Undang Nomor 6 Tahun 1983 Tentang Ketentuan Umum dan Tata Cara Perpajakan, Jakarta. Diakses 17 Juli 2007

Siti Resmi, 2010. Perpajakan : Teori dan Kasus, Jakarta : Salemba Empat

Sugiyono, 2009. Metode Penelitian Bisnis, Bandung : Alfabeta

Sutedi Andriani, 2011. Hukum Pajak, Jakarta : Sinar Grafika

Suharsimi Arikunto, 2010. Prosedur Penelitian (Edisi Revisi 2010), Jakarta : Rineka Cipta

Soemitro, 2009. Hukum Pajak, Jakarta : Sinar Grafika.

Wirawan B. Ilyas dan Richard B, 2010. Hukum Pajak, Jakarta : Salemba Empat. 